\title{
Performance Characteristics of VCR Engine using Lemon Grass Oil and Methanol Mixed with Diesel
}

\author{
M. Saravanakumar, M. Prabhahar, Manikandan.V, Sajin MP, Gangadharan.K
}

\begin{abstract}
In the Experimental study, experiments has been done on an immediate infusion, single cylinder, constant speed, water cooling system VCR engine at injection pressures 200, and compression ratio of 17.5 using various blends. The effect of dual biodiesel blends and injection pressure were examined with various engine loads.

Lemongrass oil and methanol were blended with diesel at a variety of blend ratios for the purpose of investigation. Presentation and release characteristics obtained from the systematic study reveals that Brake Thermal Efficiency (BTE) and brake specific fuel consumption (BSFC) of blend B20 (i.e. Lemongrass $20 \%$ methanol 30\% and Diesel 50\%) was higher than diesel.

The emission of carbon monoxide (CO), hydro carbons (HC), and carbon dioxides (CO2) of dual biodiesel blends with better than that of diesel. It was identified that with increase in injection pressure from 200bar can be improving the performance analysis while reducing exhaust gas emissions. But increases the nitrogen oxides emissions.
\end{abstract}

Keywords: Lemon grass biodiesel, Engine performance test, Emission test.

\section{INTRODUCTION}

The utilization of the energy is growing day by day with the increase of industrialization and growth of modern civilization. [1]The demand for biodiesel is increasing rapidly due to the small reserve of the fossil fuels and its better emission characteristics. [4]-[5]In concern of the society for the depleting world's renewable energy sources

Revised Manuscript Received on December 30, 2019.

* Correspondence Author

M.Saravanakumar*, Asst Professor Department of Mechanical Engineering, Aarupadai Veedu Institute of Technology, Vinayaka Mission Research Foundation, Chennai, India. Email: saravanakumar@avit.ac.in

M.Prabhahar, Associate Professor Department of Mechanical Engineering, Aarupadai Veedu Institute of Technology, Vinayaka Mission Research Foundation, Chennai, India. Email: mprabhahar@gmail.com org

Manikandan.V, UG Student Mechanical Department, Aarupadai Veedu Institute Of Technology, Vinayaka Mission's Research Foundation,Chennai, India.

Sajin MP, UG Student Mechanical Department, Aarupadai Veedu Institute Of Technology, Vinayaka Mission's Research Foundation, Chennai, India.

Gangadharan.K, UG Student Mechanical Department, Aarupadai Veedu Institute Of Technology, Vinayaka Mission's Research Foundation, Chennai, india.

(c) The Authors. Published by Blue Eyes Intelligence Engineering and Sciences Publication (BEIESP). This is an open access article under the CC BY-NC-ND license (http://creativecommons.org/licenses/by-nc-nd/4.0/) with fuel and energy crisis led to the search for biofuels Therefore, an investigation on Biodiesel has been chosen in this paper. The scope of this document is to evaluate the presentation and emission characteristics[2] using different mixed blends ratio of Lemongrass oils and methanol with diesel in a VCR engine.

The objectives of this[7]-[10] experimental investigation are extraction of Biodiesels (Lemon Grass Oil and Methanol) using Transesterification process, determination of the properties of dual biodiesels, study of effect of the properties of blending of dual biodiesels and diesel, [6]study of execution and emanation attributes of diesel motor using different blends of Lemon Grass Oil And Methanol with diesel. Biodiesel as the most favorable alternate is presently produced from usually grown vegetable oils, such a coconut, palm and sunflower oils [12]-[16]]Alternative fuels identified are biofuels having desirable fuel properties which are permitting them to replace the existing fuel completely. However, the researchers are working on different techniques give better solution to apply higher fraction of replacing biofuel in the existing diesel engine investigated the break thermal efficiency and[11],[13] check out to the merge misuse cooking oil $40 \%$ with waste cooking oil is marginally elevated than that of diesel at maximum solidity ratios. Waste cooking biodiesel blends provide longer combustion pressure at maximum compression ratio due to higher explosion holdup, lower heat release rate and maximum rate of force rise when compared among diesel. Brake pedal thermal efficiency of blends increase by way of increases in load. A. Sanjid et al. investigated and concluded that mustard biodiesel showed favorable biofuel properties compared to few biodiesels. From the performance and emission analysis were also found hopeful. [18-20]As conclude that mustard biodiesel $10 \%$ and $20 \%$ be capable of be used in diesel engine devoid of modifications. Srinivas et al. studied the performance as well as production individuality.

Table- I: Lemongrass oil properties

\begin{tabular}{|c|c|}
\hline Specific gravity & 0.9253 \\
\hline Density & $925.3 \mathrm{~kg} / \mathrm{m} 3$ \\
\hline Calorific value & $\begin{array}{c}8829 \mathrm{kcal} / \mathrm{kg}(37000 \\
\mathrm{kJ} / \mathrm{kg})\end{array}$ \\
\hline Kinematic viscosity & $4.16 \mathrm{Ns} / \mathrm{m} 2$ \\
\hline
\end{tabular}




\begin{tabular}{|c|c|}
\hline Specific gravity & 0.9253 \\
\hline Density & $925.3 \mathrm{~kg} / \mathrm{m} 3$ \\
\hline Flash Point & $50^{\circ} \mathrm{C}$ \\
\hline Fire point & $58^{\circ} \mathrm{C}$ \\
\hline Cetane Index & 38 \\
\hline
\end{tabular}

\section{LITERATURE REVIEW}

K. Rajan et al., [3] conducted experiment with diesel blended with sunflower oil methyl ester which condensed the production of oxides of nitrogen at $25 \%$ and other unburnt HC,CO emission are also decreased comparatively in different percentage of biodiesel blends in order of $5 \%, 10 \%, 20 \%$. Calorific value of this biodiesel is less hence BTE is increased at $4 \%$ and BSFC is increased at $10 \%$.

\section{PROPOSED SETUP AND METHODOLOGY}

The engine set up used is a computer based four caress, direct insertion, Variable Compression Ratio (VCR), diesel engine, cooling of water system and single cylinder. From the test was showed at different loads resultant in constant speed. Exhaust emission AVL gas analyzer was used to compute emissions form wear out channel tube of the engine. From the experimental on VCR diesel engine complex is given in below Finger. The thorough engine specifications are known below Table. The VCR engine run by the diesel engine through dual biodiesel ratio blends as well as contrast with the diesel this is the characteristics and performance of the VCR.

The scope of this presented paper is to evaluate the emission characteristics and performance using various mixed blends ratio of Diesel and Lemongrass oils with diesel in a VCR engine. The objectives of this experimental investigation are extraction of Biodiesels, study of presentation as well as emission individuality of diesel engine with different blends of diesel and lemongrass oils by way of diesel

The emission test is carried out during the performance test for different blends at different torque and blends. The prop is connecting with the exhaust pipe and the results were recorded by plotting the graphs for handbrake power to release limitations (CO, $\mathrm{HC}, \mathrm{CO} 2$, and $\mathrm{NOX}$ ). The value of emission parameters are measured by using AVL Gas Analyzer.

\section{RESULTS AND DISCUSSION}

The experimental data from tests on VCR engine has been systematically studied. The result of blend ratio as well as fuel vaccination pressure at compression ratio of 17.5 has been presented by varying loads. Three blends characteristics have been compared in the middle of diesel to understand the consequence of each parameter. The operation of the VCR diesel engine is found to be smooth for full load condition at different insertion pressures, Compression ratio (CR17.5:1) without any operational difficulties for the dual biodiesel blends diesel fuel (i.e. L20M10, L20M20 and L20M30).

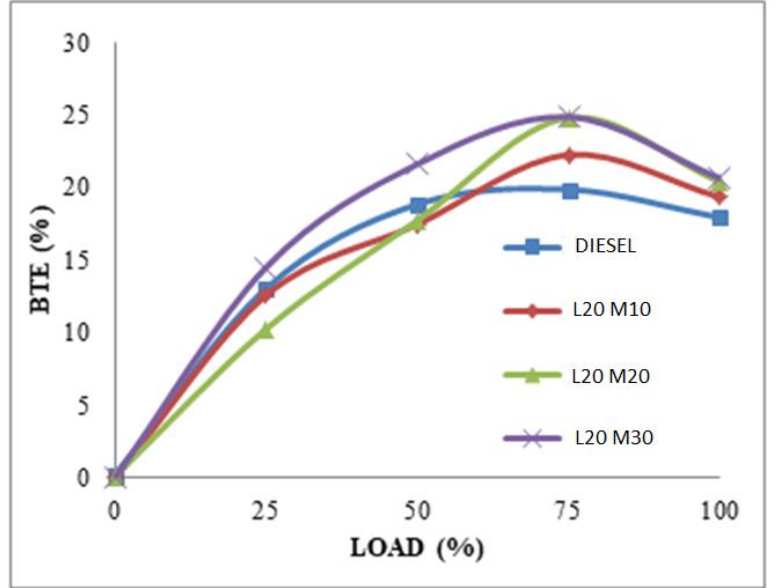

Fig. 1. BTE for various blends

Brake Thermal Efficiency (BTE) through percentage load for a variety of mixed blends is representing in above Fig. 1 . The BTE of biodiesel is advanced than diesel especially at occupied freight situation. As of the graph it is evident that the BTE is amplified through growing the blend ratio of lemongrass biodiesel. From the brake thermal efficiency of mixed blends for L20M10, L20M20 and L20M30 are 19.33 (7.8\%), 20.37 (12\%) and 20.62 (14\%) respectively higher than diesel (17.93). Even the low calorific worth of bio diesel blends than diesel; proper fuel mixing provides quality combustion. This proves that dual biodiesel provides better brake thermal efficiency than diesel.

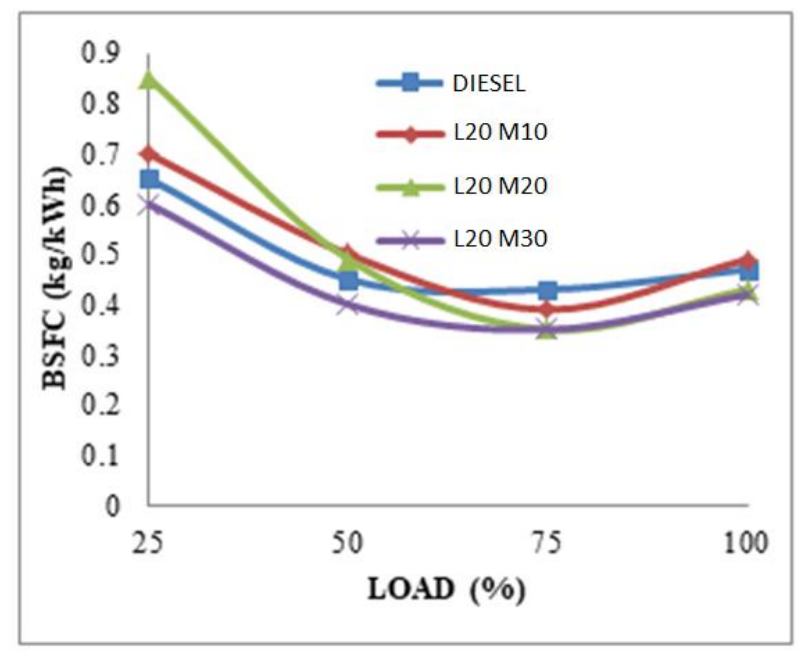

Fig. 2. Exact fuel use for a variety of blends

Fig. 2. explains that the difference of Brake Specific Fuel Consumption (BSFC) with percentage load. As load increases the BSFC and reduces the dual biodiesels mixed blends. For the maximum full load condition in compression ratio17.5 (CR17.5:1), the value of brake specific fuel consumption of mixed blends ratio B20 in L20M10, L20M20 and L20M30 showed for $0.49,0.43$ and $0.42 \mathrm{~kg} / \mathrm{kW} \mathrm{h}$ whereas diesel $(0.47 \mathrm{~kg} / \mathrm{kWh})$.

Published By:

Blue Eyes Intelligence Engineering

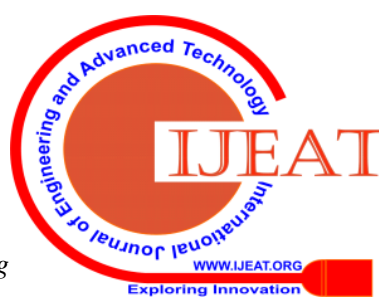




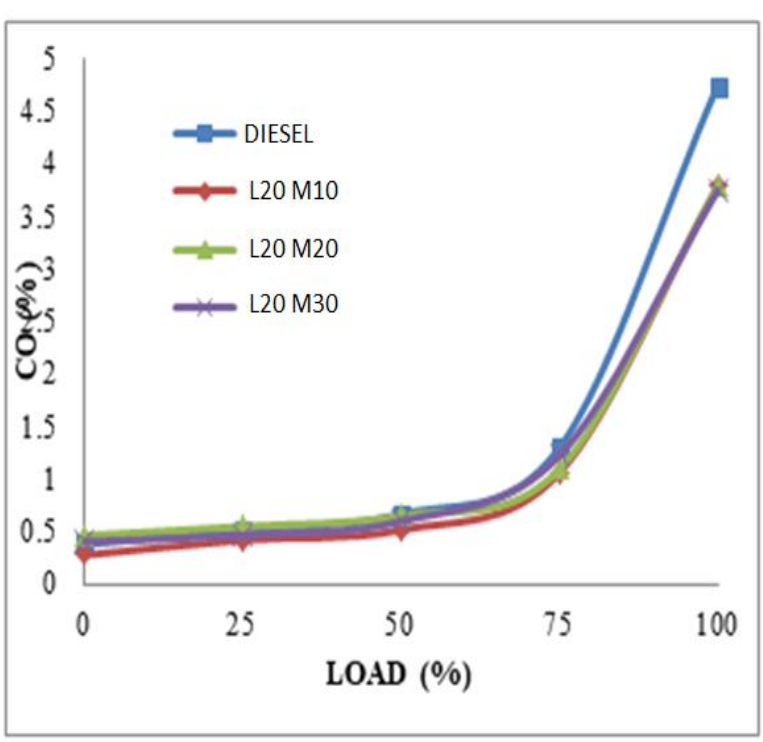

Fig. 3. Carbon monoxide for various blends

The difference of carbon monoxide through percentage load is shows in above Fig. 3. From the plot load increase the carbon monoxide also increased is observed. The CO of dual biodiesels mixed blends ratio B20 (i.e. L20M10, L20M20 and L20M30) decreases when compared to the diesel at compression ratio17.5 for full load condition (CR17.5:1), The value of carbon monoxide (CO) of mixed Blends ratio $\mathrm{B} 20$ in L20M10 is 3.78\%, L20M20 is 3.79\% and L2 M30 is $3.74 \%$ whereas diesel have $4.74 \%$.

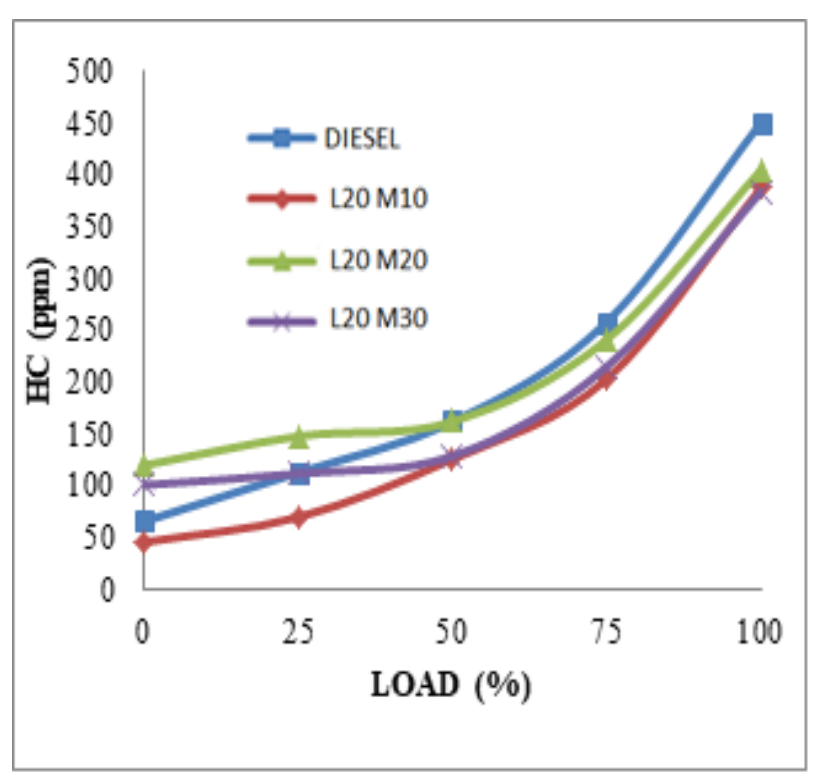

Fig. 4. difference of hydrocarbons among load

The difference of hydro carbons with percentage loads is shown in above Fig. 4. From the plot as the pack increases the hydro carbon increases is observed. At filled freight state the HC of dual biodiesel mixed blends ratioB20 (i.e. L20M10, L20M20 and L20M30) decreases when compared to the diesel in compression ratio17.5 (CR17.5:1), the value of hydro carbons (HC) of mixed blends ratio B20. L20M10 is 387 ppm L20M20 is 404 ppm and L20M30 is 383 ppm whereas diesel have $450 \mathrm{ppm}$. The emission has decreased by 14.8\% with B20 compared through diesel.

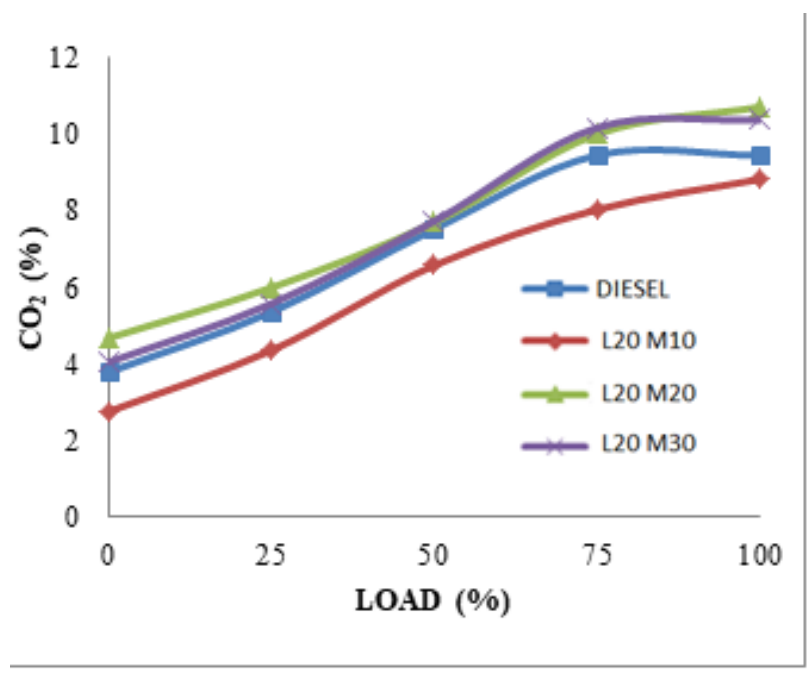

Fig. 5. difference of carbon dioxide through load

$\mathrm{CO}_{2}$ variation with its percentage of load rating is exposed in Fig. 5. From the plan that the freight increases the $\mathrm{CO}_{2}$ is also increased. The carbon dioxide of dual biodiesel mixed blends B20 (i.e. L20M10, L20M20 and L20M30) decreased when compared diesel at full load condition. As combustion product $\mathrm{CO} 2$ is shaped when present is necessary quantity of oxygen there through the configuration of carbon monoxide.

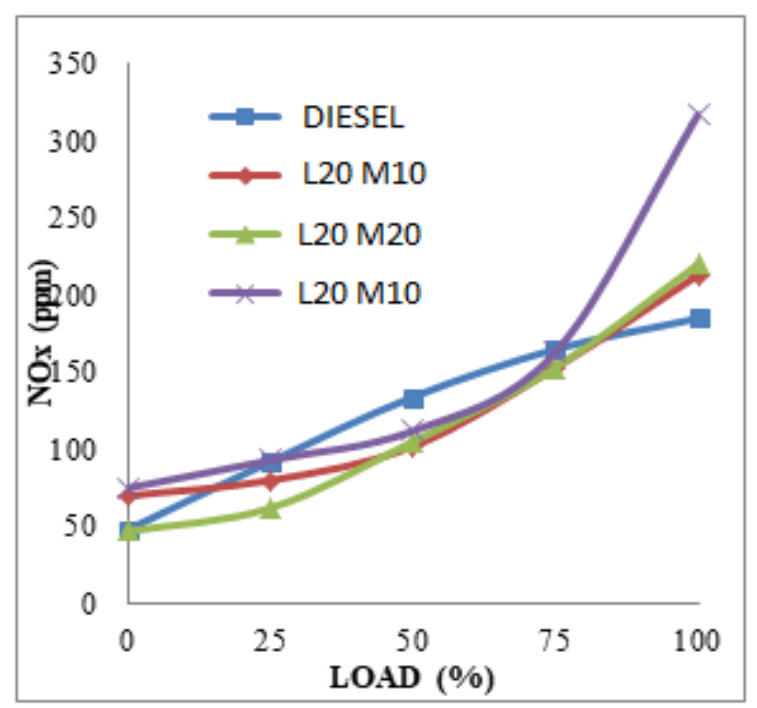

Fig. 6. Nitrogen oxides for various blends

The effect of loads on nitrogen oxides is exposed in above Fig. 6. The NOx improved at fuel load condition for every mixed blends. Each mixture blends ratio B20 (i.e L20M10, L20M20 and L20M30) are increased by nitrogen oxides (NOx). For the compression ratio 17.5 (CR17.5:1) in maximum full load condition, mixed blends ratio L20M30 gives 213 ppm and diesel is 185 ppm, L20M10 gives 220 ppm, L20M20 gives 317 ppm in the same maximum fuel load condition. From the outcomes, nitrogen oxides (NOx) outflow is higher for double biodiesel mixed blends ratio than diesel. Be that as it may, the nonedible oil with biodiesel has a necessary measure of NOx generation. Every one of the mixes give higher NOx with contrasted with diesel.

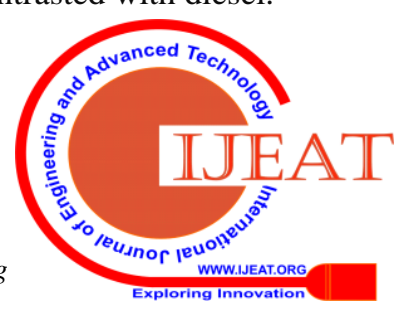


The normal temperature gas, the nearness of oxygen substance with fuel and habitation at full burden conditions with the blended mixes proportion burning caused higher Nox outflows

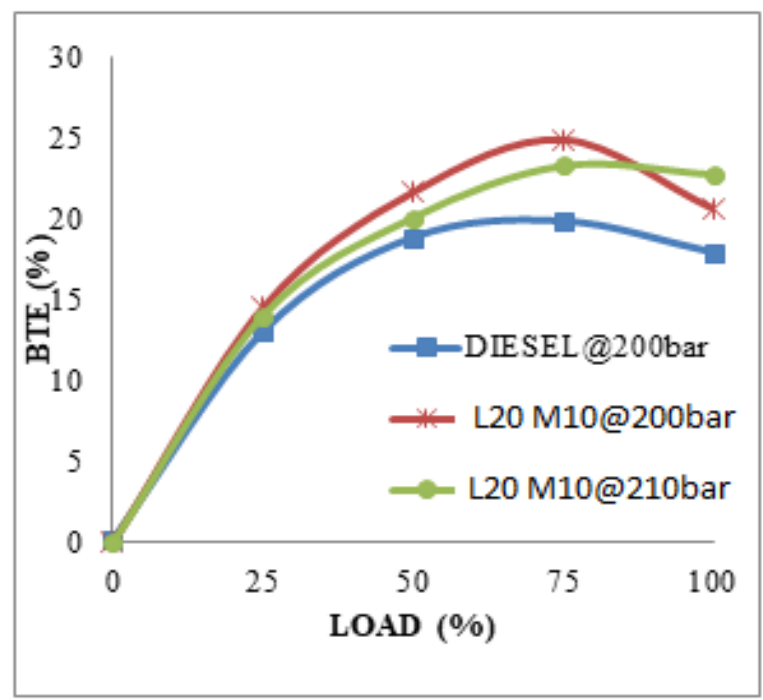

Fig. 7. difference of brake thermal effectiveness with load

Break thermal efficiency at injection pressure of 200bar and 210bar for diesel and mixed blend (L20M10) has been plotted in Fig. 7. at various loads. The break thermal efficiency of blend at 210bar is increased by $9.24 \%$ compared with 200bar.The Fig. 8. shows the difference of brake exact fuel use with load.

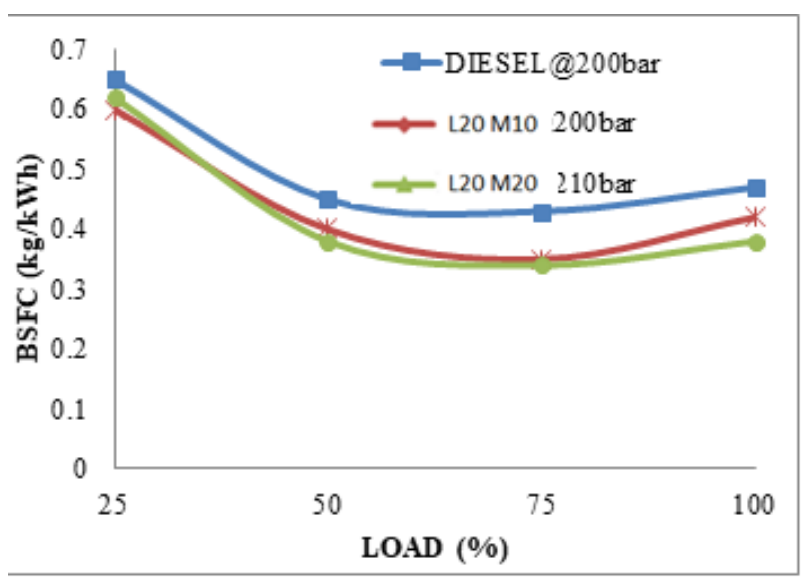

Fig. 8 difference of brake exact fuel use with load

\section{CONCLUSION}

Effects of blends on top of a solo cylinder VCR diesel engine characteristics run by dual biodiesels blend B20 mixed ratios (i.e.L20 M10, L20 M20 and L20 M30) were systematically studied. The following are the conclusions from this study. Dual Biodiesel blends with 5\% Methanol, 15\% Lemon grass oil and $80 \%$ Diesel with high injection pressure can be selected as an alternative fuel. This study provides the reliable data for researchers to choose suitable biodiesel combination. This study furnishes qualitative and quantitative information about the performance of engine with dual biodiesels. Higher BTE, lower BSFC, lower emissions are the superior qualities of the selected dual biodiesel combination. However, the NOx intensity to be reduced by choosing the suitable technology. Comparison of properties of the biodiesels such as Viscosity, calorific value, helps the engineers to choose the various combinations of blends. Performance comparison of blends with diesel engine proved that the biodiesel blends are good renewable source to meet energy crisis and to address the eco-friendly societal problem. This study augments the data base pertaining to biodiesels.

\section{REFERENCES}

1. H.E. Saleh, "Experimental study on diesel engine nitrogen oxide reduction running with jojoba methyl ester by exhaust gas recirculation," Fuel, Vol. 88, No: 8, pp.1357-1364, 2009.

2. Y.C. Sharma, B. Singh, and S.N. Upadhyay, "Advancements in development and characterization of biodiesel: A review," Journal of Fuel, Vol. 87, No: 12, pp.2355-2373, 2007.

3. K. Rajan, and K. R. Senthilkumar, "Effect of Exhaust Gas Recirculation (EGR) on the Performance and Emission Characteristics of Diese Engine with Sunflower Oil Methyl Ester," JJMIE, Vol: 3, No: 4, 2009.

4. Savita Tomar, Reena Mishra, Sarita Bisht, Sanjeev Kumar, Aman Balyan, and Mr.Gaurav Saxena, "Optimisation of Connecting Rod Design to Achieve Vcr," Int. Journal of Engineering Research and Applications, Vol. 3, No: 6, pp. 281-286, 2013. Available: www.ijera.com

5. Pooja Ghodasara, M. S. Rathore, "Prediction on Reduction of emission of nox in diesel engine using bio-diesel fuel and EGR (exhaust gas recirculation) system," International Journal of Mechanical Engineering, Vol: 1, No: 1, pp. 18-25, 2015.

6. V. Achuthanunni, B. Baiju, "Experimental Investigation of a Diesel-Biodiesel Fuelled Compression Ignition Engine with Exhaust Gas Recirculation (EGR)," IJEAT, Vol: 4, No: 1, 2014.

7. Donepudi Jagadish, Puli Ravi Kumar, and K. Madhu Murthy, "Research article performance characteristics of a diesel engine operated on biodiesel with exhaust gas recirculation," IJAET, Vol: 2, No: 2, pp. 202-208, 2011.

8. G. H. Abd-Alla, "Using exhaust gas recirculation in internal combustion engines: a review," Energy Conversion and Management, Vol: 43, No: 8, pp. 1027-1042, 2002.

9. D. Agarwal, S. Sinha, and A. K. Agarwal, "Experimental investigation of control of NOx emissions in biodiesel - fueled compression ignition engine," Renewable Energy, Vol: 31, No: 14, pp. 2356-2369, 2006.

10. K. Santoh, L. Zhang, H. Hatanaka, T. Takatsuki, and K. Yokoto, "Relationship between NOx and SM emissions from DI diesel engine with EGR," Society of Automotive engineers of Japan, Vol: 18, No: 4, pp. 369-375, 1997.

11. V. Pradeep, and R. P. Sharma, "Use of HOT EGR for NOx control in a compression ignition engine fuelled with bio- diesel from Jatropha oil," Renewable Energy, Vol: 32, No: 7, pp. 1136-1154, 2007.

12. Dan Scarpete, "Romania.Diesel-water emulsion, an alternative fuel to reduce diesel engine emissions. A review," Machines, Technologies, Materials, No: 7, pp. 13-16, 2013.

13. Y. Yoshimoto, et al, "Reduction of NOx, smoke and BSFC in a Diesel engine Fueled by Biodiesel Emulsion with Used Frying Oil," SAE paper,Vol: 108, No: 4, pp. 1913-1920, 1999.

14. Kweonha Park, Inseok Kwak, and Seungmook Oh, "The effect of water emulsified fuel on a motorway-bus diesel engine," KSME International Journal, Vol: 18, No: 11, pp. 2049- 2057, 2004.

15. N. Samec, B. Kegl, and R.W. Dibble, "Numerical and experimental study of water/oil emulsified fuel combustion in a diesel engine," Fuel, Vol: 81, No: 16, pp. 2035-2044, 2002.

16. K. Kannan, and M. Udayakumar, "NOx and $\mathrm{HC}$ emission control using water emulsified diesel in single cylinder diesel engine," ARPN Journal of Engineering and Applied Sciences, Vol: 4, No: 8, pp. 59-62, 2009.

17. R. Sathiyamoorthi, and G. Sankaranarayanan, "Experimental Investigation of Performance, Combustion and Emission characteristics of neat Lemongrass oil in DI Diesel engine," International Journal of Current Engineering and Technology, Vol: 3, pp. 25-30, 2014.

18. Sangeetha.Krishnamoorthi, et al, "Performance And Emission Characteristics Of A Diesel Engine Using Preheated Cashew Nut Shell Liquid (Cnsl)-Diesel Blend," Journal Of Chemical And Pharmaceutical Sciences, Vol: 9, No: 4, pp. 3490-3492, 2016.

Published By:

Blue Eyes Intelligence Engineering 
19. K. Sivaramakrishnan, "Investigation on performance and emission characteristics of a $61 \% 71 \% 81 \% 91 \% 10$ 1\% 11 1\% 12 1\% variable compression multi fuel engine fuelled with Karanja biodiesel-diesel blend," Egyptian Journal of Petroleum, Vol: 27, No: 1, pp. 177-186, 2017.

20. L. Prabhu, S. Satish Kumar, A. Anderson, and Rajan K, "Investigation on Performance and Emission Analysis of $\mathrm{TiO} 2$ Nanoparticle as an Additive for Bio-Diesel Blends," Journal of Chemical and Pharmaceutical Sciences, No: 7, pp. 408-412, 2015.

\section{AUTHORS PROFILE}

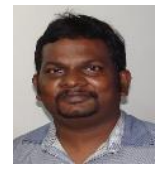

M.Saravana kumar, profile Asst Professor Department of Mechanical Engineering Aarupadai Veedu Institute of Technology Vinayaka Mission Research Foundation. saravanakumar@avit.ac.in.

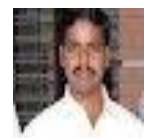

Prabhahar .M, Associate Professor Department of Mechanical Engineering Aarupadai Veedu Institute of Technology Vinayaka Mission Research Foundation mprabhahar@gmail.com

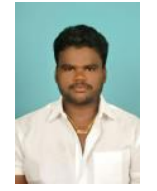

Manikandan. V, UG Student Mechanical epartment, Aarupadai Veedu Institute Of Technology, Vinayaka Mission's Research Foundation, Deemed To Be University.

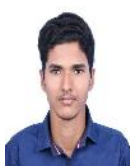

Sajin MP, UG Student Mechanical Department, Aarupadai Veedu Institute Of Technology, Vinayaka Mission's Research Foundation, Deemed To Be University.

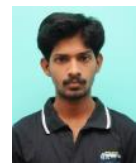

Gangadharan, EUG Student Mechanical Department, Aarupadai Veedu Institute Of Technology, Vinayaka Mission's Research Foundation, Deemed To Be University. 